\title{
Pelaksanaan Eksekusi Jaminan Fidusia Dalam Perjanjian Pembiayaan Di KSPS Logam Mulia Kecamatan Klambu Kabupaten Grobogan
}

\author{
Oleh: Junaidi Abdullah \\ abdillahrafandra@gmail.com
}

\begin{abstract}
Any loan or financing agreement made by a sharia financial institution, whether bank or non-bank, more particularly KSPS Logam Mulia, usually requires a guarantee. Guaranteed goods guaranteed by the community or its members may be movable objects such as motorcycles or cars (guaranteed by BPKB) and may be non-moving objects in the form of buildings or land (guaranteed usually land certificates).To to legalize the guarantee goods, the guarantee goods. For moving objects in the form of fiduciary and immovable property through mortgages.

With the existence of objects collateralized by the public or members of the Islamic financial institutions, both banks and non-banks with fiduciary guarantee will provide the legal force for the institution to execute objects that have been guaranteed if the people who borrow violate the promise or wanprestasi.

But in fact, KSPS Logam Mulia has never executed forcibly to the community or its members who have neglected or are unable to perform its obligations ie paying installments on loans or financing it has received.

From the results of the research can be known execution fiduciary guarantee in KSPS Logam Mulia Klambu District Grobogan District does not execute fiduciary guarantee directly against members who do not perform the obligation mengangsurnya. What factors are the background of not directly executing tehadap assurance of fiduciary objects in KSPS Logam Mulia Klambu District Grobogan Regency is: The reason shariah and Reason kinship.
\end{abstract}

Key word: Fiduciary Guarantee, Execution 


\section{A. Pendahuluan}

BMT, Koperasi Jasa Keuangan Syariah (KJKS) atau Koperasi Simpan Pinjam Syariah (KSPS) merupakan salah satu lembaga keuangan syariah. Dalam menjalankan kegiatan usahanya BMT, Koperasi Jasa Keuangan Syariah (KJKS) atau Koperasi Simpan Pinjam Syariah (KSPS) disamping menghimpun dana langsung dari masyarakat misalnya ada produk tabungan, BMT, Koperasi Jasa Keuangan Syariah (KJKS) atau Koperasi Simpan Pinjam Syariah (KSPS) juga menyalurkan dana kepada masyarakat yang membutuhkan. Penyaluran dana tersebut bisa berupa pemijaman maupun pembiayaan.

Dalam menyalurkan dana kepada masyarakat, baik berupa pinjaman maupun pembiayaan, setiap lembaga keuangan syariah baik bank maupun non bank seharusnya diikat dengan perjanjian.

Perjanjian diartikan dengan suatu perbuatan hukum, di mana satu orang atau lebih mengikatkan dirinya atau saling mengikatkan dirinya terhadap satu orang atau lebih (R. Setiawan, 1979 : 49).

Sedangkan di dalam KUHPerdata istilah perjanjian (kontrak) dibahas dalam Buku III tentang perikatan, dalam pasal 1313 merumuskan perjanjian sebagai berikut : “ Perjanjian adalah suatu perbuatan dengan mana satu orang atau lebih mengikatkan dirinya terhadap satu orang lain tau lebih".

Dengan adanya perjanjian, maka akan terjadi hubungan hukum antara kedua belah pihak yang berjanji. Abdulkadir Muhammad menyatakan hubungan hukum yang terjadi karena perjanjian contohnya adalah jual beli, sewa menyewa, utang-piutang, tukar-menukar dan pemberian kuasa; ketentuan undang-undang yang saling menguntungkan bagi pihak-pihak, misalnya perwakilan sukarela (zaakwaarneming), pembayaran tanpa utang (onverschuldigde betaling), perbuatan menurut hukum (rechtmatige daad) dan pewarisan; ketentuan undang-undang yang merugikan orang lain, misalnya perbuatan melawan hukum (onrechtmatige daad) (Abdulkadir Muhammad, 2010 : 2-3). 
Dalam pinjaman atau pembiayaan yang dilakukan oleh KSPS Logam Mulia Klambu kabupaten Grobogan terhadap masyarakat atau anggotanya tentu telah diikat dengan perjanjian. Dengan disepakatinya perjanjian antara kedua belah pihak (antara KSPS Logam Mulia dengan masyarakat atau anggotanya) maka sudah terjadi hubungan hukum.

Setiap perjanjian pinjaman atau pembiayaan yang dilakukan oleh lembaga keuangan syariah baik bank maupun non bank, lebih khususnya KSPS Logam Mulia, biasanya memerlukan jaminan. Barang jaminan yang dijaminkan masyarakat atau anggotanya bisa berupa benda bergerak seperti motor atau mobil (yang dijaminkan BPKB) dan bisa berupa benda tidak bergerak baik berupa bangunan maupun tanah (yang dijaminkan biasanya sertifikat tanahnya).

Maka untuk melegalkan barang jaminan tersebut, wajib bagi lembaga mendaftarkan barang jaminan tersebut. Untuk benda bergerak berupa jaminan fidusia dan benda tidak bergerak melalui hak tanggungan,

Fidusia adalah pengalihan hak kepemilikan suatu benda atas dasar kepercayaan dengan ketentuan bahwa benda yang hak kepemilikannya dialihkan tersebut tetap dalam penguasaan pemilik benda. Sedangkan Jaminan Fidusia adalah hak jaminan atas benda bergerak baik yang berwujud maupun yang tidak berwujud dan benda tidak bergerak khususnya bangunan yang tidak dapat dibebani hak tanggungan sebagaimana dimaksud dalam Undangundang Nomor 4 Tahun 1996 tentang Hak Tanggungan yang tetap berada dalam penguasaan Pemberi Fidusia,sebagai agunan bagi pelunasan utang tertentu, yang memberikan kedudukan yang diutamakan kepada Penerima Fidusia terhadap kreditor lainnya. (Undang Undang Nomor 42 Tahun 1999 Tentang jaminan Fidusia).

Sedangkan yang dimaksud dengan Hak Tanggungan atas tanah beserta benda-benda yang berkaitan dengan tanah, yang selanjutnya disebut Hak Tanggungan, adalah hak jaminan yang dibebankan pada hak atas tanah sebagaimana dimaksud dalam Undang-Undang Nomor 5 Tahun 1960 tentang Peraturan Dasar Pokok-Pokok Agraria, berikut atau tidak berikut benda-benda lain yang 
merupakan satu kesatuan dengan tanah itu, untuk pelunasan utang tertentu, yang memberikan kedudukan yang diutamakan kepada kreditor tertentu terhadap kreditor-kreditor lain.( Undang Undang Nomor 4 tahun 1996 tentang Hak Tanggungan).

Dengan adanya benda yang dijadikan agunan oleh masyarakat atau anggota dari lembaga keuangan syariah baik bank maupun non bank dengan jaminan fidusia akan memberikan kekuatan hukum bagi pihak lembaga untuk megeksekusi benda yang sudah dijaminkan apabila masyarakat yang pinjam melanggar janji atau wanprestasi.

Namun pada faktanya, pihak KSPS Logam Mulia tidak pernah melakukan eksekusi secara paksa kepada masyarakat atau anggotanya yang telah lalai atau tidak mampu melaksanakan kewajibannya yakni membayar angsuran atas pinjaman atau pembiayaan yang telah diterimanya. (Hasil wawancara dengan Bapak Agus Sugianto selaku manajer marketing KSPS Logam Mulia pada tanggal 3 Maret 2016).

Padahal dengan adanya jaminan fidusia yang telah dilakukan oleh KSPS Logam Mulia, benda bergerak berupa sepeda motor atau mobil milik masyarakat atau anggota yang tidak membayar berhak atau dapat di eksekusi secara langsung oleh KSPS Logam Mulia kecamatan Klambu kabupaten Grobogan.

\section{B. Pembahasan}

\section{Jaminan Fidusia}

\section{a. Pengertian Fidusia dan Jaminan fidusia}

Kata fidusia berasal dari bahasa latin 'fiduciair' yang berarti 'secara kepercayaan' (R. Subekti, R. Tjitrosoedibio, 1994 : 42), kepercayaan yang dimaksud adalah kepercayaan yang diberikan dari debitur kepada kreditur sebagai pemindahan milik atau untuk suatu jaminan saja guna keperluan utang,

Fidusia adalah pengalihan hak kepemilikan suatu benda atas dasar kepercayaan dengan ketentuan bahwa benda yang hak kepemilikannya dialihkan tersebut tetap dalam penguasaan pemilik benda Pasal 1 Undang-Undang Nomor 42 
tahun 1999 tentang Jaminan Fidusia) (UndangUndang Nomor 42 tahun 1999 tentang Jaminan Fidusia).

Sedangkan Jaminan fidusia adalah hak jaminan atas benda bergerak baik yang berwujud maupun yang tidak berwujud dan benda tidak bergerak khususnya bangunan yang tidak dapat dibebani hak tanggungan sebagaimana dimaksud dalam Undang-Undang Nomor 4 Tahun 1996 tentang Hak Tanggungan yang tetap berada dalam penguasaan Pemberi Fidusia, sebagai agunan bagi pelunasan utang tertentu, yang memberikan kedudukan yang diutamakan kepada Penerima Fidusia terhadap kreditor lainnya. (Pasal 1 Undang-Undang Nomor 42 tahun 1999 tentang Jaminan Fidusia).

Daei pengertian jamonan fidusia di atas, maka unsur-unsur dari Jaminan Fidusia, meliputi:

1. Jaminan fidusia merupakan lembaga hak jaminan kebendaan

2. Obyek jaminan fidusia adalah benda bergerak dan benda tidak bergerak khususnya bangunan yang tidak dibebani dengan hak tanggungan

3. Benda yang menjadi objek jaminan fidusia tersebut adalah sebagai agunan atau jaminan untuk pelunasan suatu utang tertentu

4. Memberikan kedudukan yang diutamakan kepeda lembaga pembiayaan terhadap kreditur lainnya.

b. Obyek dan Subyek Jaminan Fidusia

Dari pengertian di atas, maka obyek jaminan fidusia meliputi:

a. benda bergerak yang berwujud

b. benda bergerak yang tidak berwujud

c. benda tidak bergerak khususnya bangunan yang tidak dapat dibebani hak tanggungan

Sedangkan subyek dari jaminan fidusia adalah adalah mereka yang dapat engikatkan diri dalam perjanjian jaminan fidusia, yang terdiri dari atas pihak debitur sebagai pemberi fidusia dan lembaga pembiayaan (kreditur) sebagai penerima 
fidusia . (Undang-Undang Nomor 42 tahun 1999 tentang Jaminan Fidusia).

\section{c. Eksekusi Jaminan Fidusia}

Lembaga Jaminan Fidusia emungkinkan kepada para pemberi fidusia untuk menguasai benda yang dijaminkan, untuk melakukan kegiatan usaha yang dibiayai dari pinjaman dengan menggunakan jaminan fidusia. Pada awalnya, benda yang menjadi obyek fidusia terbatas pada kekayaan benda bergerak yang berwujud dalam bentuk peralatan. Akan tetapi dalam perkembangan selanjutnya, benda yang menjadi obyek fidusia termasuk juga kekayaan benda bergerak yang tak berwujud, maupun benda tak bergerak.

Dalam pelaksanaan pembiayaan antara kreditur dan debitur, kadangkala terjadi wanprestasi atau ingkar janji. Maka, ketika debitur ingkar janji pihak kreditur bisa melakukan eksekusi benda yang sudah dijaminkan melalui jaminan fidusia.

Menurut Subekti, yang dimaksud dengan eksekusi adalah upaya dari pihak yang dimenangkan dalam putusan guna mendapatkan yang menjadi haknya dengan bantuan kekuatan hukum, memaksa pihak yang dikalahkan untuk melaksanakan putusan (Subekti, 1997 : 128)..

Sedangkan menurut Retnowulan Sutantio dan Iskandar Oeripkartawinata menyatakan, bahwa Eksekusi adalah Tindakan paksaan oleh Pengadilan terhadap pihak yang kalah dan tidak mau melaksanakan putusan dengan sukarela (Renowulan Sutantio dan Iskandar Oeripkartawinata, $1997: 10)$.

Dengan debitur yang ingkar janji, maka kreditur bisa langsung mengeksekusi benda jaminan yang dijaminkan fidusia. Karena di dalam sertifikat jaminan fidusia memuat ketentuan katakata " DEMI KEADILAN BERDASARKAN KETUHANAN YANG MAHA ESA". Dengan 
kata-kata ini, maka mempunyai kekuatan hukum seperti keputusan pengadilan.

Hal ini sesuia dengan undang-undang nomor 42 tahun 1999 tentang Jaminan Fidusia yang menyatakan, apabila debitor atau pemberi fidusia cidera janji, eksekusi terhadap benda yang menjadi obyek jaminan fidusia dapat dilakukan dengan cara :

a. Pelaksanaan titel eksekutorial oleh penerima fidusia

b. Penjualan benda yang menjadi obyek jaminan fidusia atas kekuasaan penerima fidusia sendiri melalui pelelangan umum serta mengambil pelunasan piutangnya dari hasil penjualan

c. Penjualan di bawah tangan yang dilakukan berdasarkan kesepakatan pemberi dan penerima fidusia jika dengan cara demikian dapat diperoleh harga tertinggi yang menguntungkan para pihak.

Pelaksanaan penjualan di dawah tangan dilakukan setelah lewat waktu 1 (satu) bulan sejak diberitahukan secara tertulis oleh pemberi dan atau penerima fidusia kepada pihak-pihak yang berkepentingan dan diumumkan sedikitnya dalam 2 (dua) surat kabar yang beredar di daerah yang bersangkutan.

Dalam undang-undang jaminan fidusia uga diterangkan, bahwa pemberi fidusia wajib menyerahkan benda yang obyek jaminan fidusia dalam rangka pelaksanaan eksekusi jaminan fidusia.

Dalam hal Benda yang obyek jaminan fidusia terdiri atas benda perdagangan atau efek yang dapat dijual di pasar atau di bursa, penjualannya dapat dilakukan di tempat-tempat tersebut sesuai dengan peraturan perundangundangan yang berlaku.

Setiap janji untuk melaksanakan eksekusi terhadap benda yang menjadi obyek jaminan fidusia dengan cara yang bertentangan dengan ketentuan di atas maka batal demi hukum. 
Setiap janji yang memberikan kewenangan kepada penerima fidusia untuk memiliki benda yang menjadi obyek jaminan fidusia apabila debitor cidera janji, batal demi hukum.

Dalam hal eksekusi melebihi nilai penjaminan, penerima fidusia wajib mengembalikan kelebihan tersebut kepada pemberi fidusia. Apabila hasil eksekusi tidak mencukupi untuk pelunasan utang, debitor tetap bertanggung jawab atas utang yang belum terbayar.

2. Eksekusi jaminan fidusia di KSPS Logam Mulia Kecamatan Klambu Kabupaten Grobogan

Sebeum berbicara mengenai eksekusi jaminan fidusia, maka perlu dibahas mengenai prosedur jaminan fidusia yang dilakukan oleh KSPS Logam Mulia. Dari wawancara didapatkan bahwa prosedur tetap yang dilakukan oleh KSPS adalah:

Ketika calon anggota yang ingin melakukan pembiayaan ke KSPS, calon anggota tersebut datang langsung, dengan membawa persyaratan-persyaratan yang ada dengan membawa jaminan BPKB Mobil atau motor. Setelah persyuaratan diterima maka pihak KSPS melakukan suevey layak tidaknya caon anggota mendapatkan pembiayaan". (Hasil wawancara dengan bapak Agus pada tanggal 28 Juni 2016).

"Seielah dianggap memenuhi persyaratan dan layak, maka calon anggota tersebut dipanggil untuk melaksanakan perjanjian pembiayaan dengan membayar uang administrasi, biaya asuransi biaya nitaris dan biaya jaminan fidusia atas jaminan BPKB yang dibayar oleh anggota. Semuanya di depan notaries Kudus yang menjalin kerja sama dengan KSPS Logam Mulia. (Hasil wawancara dengan bapak Agus pada tanggal 28 Juni 2016).

"Namun tidak semua jaminan BPKB benda bergerak di jaminkan fidusia, tetapi yang dijaminkan fidusia hanya benda bergerak mobil yang harganya di atas 20 juta dan nominalnya peminjamannya di atas 20 juta. Sedangkan jaminan benda bergerak berpa swpwda motor tidak dijaminkan yang nominal 
peminjamannya dari 1-10 juta" (Hasil wawancara dengan bapak Agus pada tanggal 28 Juni 2016).

Setelah pembiayaan cair, maka anggota harus melaksanakan kewajibannya dengan mengangsur tiap bulan yang sudah di sepakati secara bersama-sama, namun kadangkala ada anggota yang bermasalah dengan tidak membayar angsuran baik yang di sengaja maupun tidak dan dengan berbagai alas an. Hal ini tentu membuat KSPS Logam Mulia berusaha untuk memotivasi anggota yang melanggar untuk membayar angsurannya kembali, baik itu melalui surat peringatan maupun dengan cara-cara yang lainnya.

Setelah berbagai cara telah dilakukan, sebenarnya pihak KSPS punya hak untu menyita benda bergerak yang telah dijaminkan kepada KSPS Logam Mulia dengan jaminan fidusia, akan tetapi pihak KSPS belum pernah melakukan eksekusi jaminan fidusi. Teyapi yang dilakukan oleh phak KSPS logam Mulia dengan pendekatan musyawarah dan kekeluargaan, yakni caranya anggota yang tidak mampu mengangsur untuk menjual sendiri atau dibantu oleh KSPS Logam Mulia dengan menjualkan benda bergerak yang dijaminkan fidusia. Setelah laku, maka hasil penjualannya diserahkan kepada pihak KSPS Logam Mulia untuk melunasi sisa angsuran yang nunggak dan ketika ada kelebihan uang dalam pelunasan pembiayaan maka sisa uang tersebut diserahkan kembali kepada anggota yang bersangkutan (Hasil wawancara dengan bapak Agus pada tanggal 28 Juni 2016).

Dari hasil wawancara di atas, maka dapat disimpulkan bahwa pihak KSPS Logam Mulia tidak melakukan eksekusi jaminan fidusia terhadap anggota yang tidak melakukan kewajiban mengangsurnya.

Secara prosedur, proses terjadinya jaminan fidusia yang dilakukan oleh pihak KSPS Logam Mulia sudah sesuai dengan aturan main atau hukum yang berlaku di Indonesia, yakni mengacu pada undangundang nomor 42 tahun 1992 tentang Jaminan Fidisia. 
Menurut undang-undang nomor 42 tahun 1999, Jaminan fidua terjadi melalui 2 tahapan :

1. Tahapan Pembebanan Jaminan Fidusia

Jaminan fidusia merupakan perjanjian ikutan dari suatu perjanjian pokok yang menimbulkan kewajiban bagi para pihak untuk memenuhi suatu prestasi. Pembebanan benda dengan jaminan fidusia dibuat dengan akta notaris dalam Bahasa Indonesia dan merupakan akta jaminan fidusia. Terhadap pembuatan akta jaminan fidusia dikenakan biaya.

Akta jaminan fidusia kurangnya memuat:

a. Identitas pihak Pemberi dan Penerima fidusia

b. Data perjanjian pokok yang dijamin fidusia

c. Uraian mengenai Benda yang menjadi obyek JaminaFidusia

d. Nilai penjaminan

e. Nilai Benda yang menjadi obyek Jaminan Fidusia.

2. Tahapan Pendaftaran Jaminan Fidusia

Benda yang dibebani dengan jaminan fidusia wajib didaftarkan. Walaupun benda yang dijaminkan fidusia berada di luar wilayah republic Indonesia. Pendaftaran jaminan fidusia dilakukan pada Kantor pendaftaran fidusia. Permohonan pendaftaran jaminan fidusia dilakukan oleh penerima fidusia, kuasa atau wakilnya dengan melampirkan pernyataan pendaftaran jaminan fidusia.

Pernyataan pendaftaran memuat:

a. Identitas pihak Pemberi dan Penerima Fidusia

b. Tanggal, nomor akta jaminan Fidusia, nama, tempat kedudukan notaris yang membuat akta Jaminan Fidusia

c. Data perjanjian pokok yang dijamin fidusia

d. Uraian mengenai Benda yang menjadi obyek Jaminan Fidusia

e. Nilai penjaminan

f. Nilai benda yang menjadi obyek Jaminan Fidusia.

Kantor pendaftaran fidusia mencatat jaminan fidusia dalam Buku Daftar Fidusia pada tanggal yang sama dengan tanggal penerimaan 
permohonan pendaftaran. Kantor pendaftaran fidusia menerbitkan dan menyerahkan kepada penerima fidusia pada tanggal yang sama dengan tanggal penerimaan permohonan pendaftaran. Sertifikat Jaminan Fidusia yang merupakan salinan dari Buku Daftar Fidusia memuat catatan tentang hal-hal persyaratan-persyaratan pendaftaran jaminan fidusia. Jaminan fidusia lahir pada tanggal yang sama dengan tanggal dicatatnya jaminan Fidusia dalam Buku Daftar Fidusia (Undangundang nomor 42 tahun 1999 tentang Jaminan fidua).

Kemudian tata cara pendaftaran jaminan fidusia telah diatur didalam Peraturan Pemerintah Nomor 86 tahun 2000 ientang Tata Cara Pendaftaran Jaminan Fidusia Dan Biaya Pembuatan Akta Jaminan Fidusia yang telah dirubah oleh Peraturan Pemerintah Nomor 21 tahun 2015 ientang Tata Cara Pendaftaran Jaminan Fidusia Dan Biaya Pembuatan Akta Jaminan Fidusia.

Permohonan pendaftaran jaminan fidusia memuat:

a. identitas pihak Pemberi Fidusia dan Penerima Fidusia

b. tanggal, nomor akta Jaminan Fidusia, nama, dan tempat kedudukan notaris yang membuat akta Jaminan Fidusia

c. data perjanjian pokok yang dijamin fidusia

d. uraian mengenai benda yang menjadi objek Jaminan Fidusia

e. nilai penjaminan

f. nilai benda yang menjadi obyek Jaminan Fidusia.(pasal 3 Peraturan Pemerintah Nomor 21 tahun 2015 tentang Tata Cara Pendaftaran Jaminan Fidusia Dan Biaya Pembuatan Akta Jaminan Fidusia).

Permohonan pendaftaran Jaminan Fidusia diajukan dalam jangka waktu paling lama 30 (tiga puluh) hari terhitung sejak tanggal pembuatan akta Jaminan Fidusia. Permohonan pendaftaran Jaminan 
Fidusia yang telah memenuhi ketentuan atau memenuhi syarat-syarat memperoleh bukti pendaftaran.

Bukti pendaftaran paling sedikit memuat:

a. nomor pendaftaran

b. tanggal pengisian aplikasi

c. nama pemohon

d. nama Kantor Pendaftaran Fidusia

e. jenis permohonan

f. biaya pendaftaran Jaminan Fidusia .(pasal 5 Peraturan Pemerintah Nomor 21 tahun 2015 ientang Tata Cara Pendaftaran Jaminan Fidusia Dan Biaya Pembuatan Akta Jaminan Fidusia).

Pemohon melakukan pembayaran biaya pendaftaran jaminan fidusia melalui bank persepsi berdasarkan bukti pendaftaran. Pendaftaran jaminan fidusia dicatat secara elektronik setelah pemohon melakukan pembayaran biaya pendaftaran jaminan fidusia.

Jaminan fidusia lahir pada tanggal yang sama dengan tanggal jaminan fidusia dicatat. Sertifikat jaminan fidusia ditandatangani secara elektronik oleh Pejabat pada kantor pendaftaran fidusia. Sertifikat jaminan fidusia dapat dicetak pada tanggal yang sama dengan tanggal Jaminan Fidusia dicatat.

Dalam hal terjadi kesalahan pengisian data dalam permohonan pendaftaran jaminan fidusia yang diketahui setelah sertifikat jaminan fidusia dicetak, penerima fidusia, kuasa atau wakilnya harus mengajukan permohonan perbaikan sertifikat jaminan fidusia kepada Menteri. Permohonan perbaikan sertifikat jaminan fidusia paling sedikit memuat :

a. nomor dan tanggal sertifikat Jaminan Fidusia yang akan diperbaiki

b. data perbaikan

c. keterangan perbaikan .(pasal 9 ayat 2 Peraturan Pemerintah Nomor 21 tahun 2015 ientang Tata Cara Pendaftaran Jaminan Fidusia Dan Biaya Pembuatan Akta Jaminan Fidusia). 
Permohonan perbaikan sertifikat jaminan fidusia melampirkan:

a. salinan sertifikat Jaminan Fidusia yang akan diperbaiki

b. fotokopi bukti pembayaran biaya pendaftaran Jaminan Fidusia

c. salinan akta Jaminan Fidusia .(pasal 9 ayat 3 Peraturan Pemerintah Nomor 21 tahun 2015 ientang Tata Cara Pendaftaran Jaminan Fidusia Dan Biaya Pembuatan Akta Jaminan Fidusia).

Permohonan perbaikan sertifikat jaminan fidusia diajukan dalam jangka waktu paling lama 30 (tiga puluh) hari terhitung sejak tanggal sertifikat jaminan fidusia diterbitkan.

Dalam sertifikat jaminan fidusia dicantumkan kata-kata "DEMI KEADILAN BERDASARKAN KETUHANAN YANG MAHA ESA". Sertifikat jaminan fidusia mempunyai kekuatan eksekutorial yang sama dengan putusan pengadilan yang telah memperoleh kekuatan hukum tetap. Apabila debitor cidera janji, penerima fidusia mempunyai hak untuk menjual benda yang menjadi obyek jaminan fidusia atas kekuasaannya sendiri.

Secara hukum eksekusi bisa dilakukan secara langsung terhadap benda bergerak yang dijaminkan fidusia. Karena secara tekstual telah diatur dalam undang-undang nomor 42 tahun 1999 tentang jaminan Fidusia dan Peraturan Pemerintah Nomor 21 tahun 2015 ientang Tata Cara Pendaftaran Jaminan Fidusia Dan Biaya Pembuatan Akta Jaminan Fidusia.

Sta eksekutorial tercantum dalam sertifikat jaminan fidusia yang berbunyi "DEMI KEADILAN BERDASARKAN KETUHANAN YANG MAHA ESA"., sehingga ketika anggota yang tidak melaksanakan kewajibannya, maka obyek yang dijaminkan bisa secara langsung di eksekusi tanpa melalui proses hukum, karena sita eksekutorial mempunyai kekuatan hukum yang sama seperti putusan pengadilan. 
Dengan tidak dilakukannya sita eksekutorial yang dilakukan oleh KSPS Logam Mulia menunjukkan bahwa pihak KSPS Logam Mulia tidak menerapkan hukum yang berlaku, tetapi lebih mengutamakan penyelesaian tanpa prosedur hukum dan lebih ke non litigasi yakni jalur musyawarah.

3. Faktor-Faktor apa saja yang melatar belakangi tidak dilakukannya eksekusi secara langsung tehadap benda jaminan fidusia di KSPS Logam Mulia Kecamatan Klambu Kabupaten Grobogan

Sebenarnya eksekusi terhadap jaminan yang sudah dijaminkan secara fidusia itu bisa dilakukan secara langsung oleh kreditur kepada pihak debitur (pihak KSPS Logam Mulia kepada anggota yang melalaikan kewajibannya. Namun, hal tersebut tidak dilakukan dengan berbagai alas an.

‘KSPS Logam Mulia tidak melaksanakan eksekusi jaminan fi dusia karena pihak yayasan dan pengurus serta DPS tidak membolehkan, secara syariah orang yang berhutang itu dalam kondisi yang susah, apalagi jetika tidak mampu bayar maka akan lebih susah, kalau sampai jaminannya di sita secara langsung dan paksa tentu akan lebih menyusahkan lagi, maka sebagai lembaga pembiayaan yang berprinsipkan syariah harus menerapkan prinsip saling tolong-menolong, kesepakatan bersama (Hasil wawancara dengan bapak Agus pada tanggal 28 Juni 2016).

"KSPS tidak mengeksekusi secara langsung benda yang dijaminkan secara fidusia dan memilih pendekatan secara kekeluargaan, yakni pihak anggota di datangi di rumah untuk bermusyawarah dan memberikan masukan supaya benda yang dijaminkan secara fidusia di jual sendiri atau dijualkan oleh pihak KSPS Logam Mulia. Dimana hasil penjualannya digunakan untuk melunasi angsuran yang macet, ketiaka ada sisa, maka uangnya akan dikembalikan kepada amggota tersebut (Hasil wawancara dengan bapak Agus pada tanggal 28 Juni 2016). 
Dari hasil wawancara di atas, maka dapat disimpulkan, bahwa KSPS Logam Mulia tidak mengeksekusi secara langsung benda yang dijaminkan secara fidusia adalah :

1. Alasan syariah

2. Alasan kekeluargaan

Dalam pelaksanaan pembiayaan antara KSPS Logam Mulia dan anggotanya, kadangkala terjadi wanprestasi atau ingkar janji. Maka, ketika amgota ingkar janji pihak KSPS Logam Mulia bisa melakukan eksekusi benda yang sudah dijaminkan melalui

Dengan anggota yang ingkar janji, maka KSPS Logam Mulia bisa langsung mengeksekusi benda jaminan yang dijaminkan fidusia. Karena di dalam sertifikat jaminan fidusia memuat ketentuan kata-kata "DEMI KEADILAN BERDASARKAN KETUHANAN YANG MAHA ESA". Dengan kata-kata ini, maka mempunyai kekuatan hukum seperti keputusan pengadilan.

Hal ini sesuia dengan undang-undang nomor 42 tahun 1999 tentang Jaminan Fidusia yang menyatakan, apabila debitor atau pemberi fidusia cidera janji, eksekusi terhadap benda yang menjadi obyek jaminan fidusia dapat dilakukan dengan cara :

a. pelaksanaan titel eksekutorial oleh penerima fidusia

b. penjualan benda yang menjadi obyek jaminan fidusia atas kekuasaan penerima fidusia sendiri melalui pelelangan umum serta mengambil pelunasan piutangnya dari hasil penjualan

c. penjualan di bawah tangan yang dilakukan berdasarkan kesepakatan pemberi dan penerima fidusia jika dengan cara demikian dapat diperoleh harga tertinggi yang menguntungkan para pihak.

Pelaksanaan penjualan di dawah tangan dilakukan setelah lewat waktu 1 (satu) bulan sejak diberitahukan secara tertulis oleh pemberi dan atau penerima fidusia kepada pihak-pihak yang berkepentingan dan diumumkan sedikitnya dalam 2 (dua) surat kabar yang beredar di daerah yang bersangkutan. 
Dalam undang-undang jaminan fidusia uga diterangkan, bahwa pemberi fidusia wajib menyerahkan benda yang obyek jaminan fidusia dalam rangka pelaksanaan eksekusi jaminan fidusia.

Dalam hal Benda yang obyek jaminan fidusia terdiri atas benda perdagangan atau efek yang dapat dijual di pasar atau di bursa, penjualannya dapat dilakukan di tempat-tempat tersebut sesuai dengan peraturan perundang-undangan yang berlaku.

Setiap janji untuk melaksanakan eksekusi terhadap benda yang menjadi obyek jaminan fidusia dengan cara yang bertentangan dengan ketentuan di atas maka batal demi hukum.

Setiap janji yang memberikan kewenangan kepada penerima fidusia untuk memiliki benda yang menjadi obyek jaminan fidusia apabila debitor cidera janji, batal demi hukum.

Dalam hal eksekusi melebihi nilai penjaminan, penerima fidusia wajib mengembalikan kelebihan tersebut kepada pemberi fidusia. Apabila hasil eksekusi tidak mencukupi untuk pelunasan utang, debitor tetap bertanggung jawab atas utang yang belum terbayar.

Namun sita eksekutorial tidak dilakukan oleh pihak KSPS Logam Mulia demgan alas an syariah dan mengedepankan kekeluargaan. Dengan alas an tersebut, menurut hemat penulis itu juga baik dilakukan supaya anggotanya tetap melakukan pembiayaan di KSPS Logam Mulia dan bisa memberikan masukan kepada saudara maupun tetangganya, karena pelaksanaan eksekusi tidak dilakukan, tetapi melakukan musyawarah dengan memberikan masukan penjualan barang yang dijaminkan.

\section{Kesimpulan}

Setelah diadakan pembahasan, maka dapat disimpulkan, bahwa :

1. Eksekusi jaminan fidusia di KSPS Logam Mulia Kecamatan Klambu Kabupaten Grobogan

Bahwa pihak KSPS Logam Mulia tidak melakukan eksekusi jaminan fidusia secara langsung 
terhadap anggota yang tidak melakukan kewajiban mengangsurnya.

2. Faktor-Faktor apa saja yang melatar belakangi tidak dilakukannya eksekusi secara langsung tehadap benda jaminan fidusia di KSPS Logam Mulia Kecamatan Klambu Kabupaten Grobogan

Bahwa KSPS Logam Mulia tidak mengeksekusi secara langsung benda bergerak yang dijaminkan secara fidusia adalah:

1. Alasan syariah

2. Alasan kekeluargaan 
Junaidi Abdullah

\section{Daftar Pustaka}

Abdulkadir Muhammad, Hukum Perdata Indonesia, Citra Aditya Bakti, Bandung, 2010

A Hamzah dan Senjun Manulang, Lembaga Fidusia dan Penerapannya di Indonesia, Hill.co, Jakarta, 1987

R. setiawan, , Pokok Pokok Hukum Perikatan, Binacipta, Bandung 1979

Renowulan Sutantio dan Iskandar Oeripkartawinata, Hukum Acara Perdata Dalam Teori dan Praktek, PT. Mandar Maju, Bandung, 1997

R. Subekti, R. Tjitrosoedibio, Kamus Hukum, Pradnya Paramita, Jakarta, 1994

Subekti, Hukum Acara Perdata, Bina Cipta. Bandung, 1997

Kitab Undang Undang Hukum Perdata

Undang Undang Nomor 42 Tahun 1999 Tentang jaminan Fidusia

Undang Undang Nomor 4 tahun 1996 tentang Hak Tanggungan \

Peraturan Pemerintah Nomor 21 tahun 2015 ientang Tata Cara Pendaftaran Jaminan Fidusia Dan Biaya Pembuatan Akta Jaminan Fidusia. 